\title{
Comprehensive quantitation of metabolite concentrations, gross reaction fluxes, and reaction free energies across cells from four organisms
}

\author{
Junyoung Park ${ }^{1,2^{*}}$, Sara Rubin ${ }^{3}$, Yi-Fan Xu ${ }^{1,3}$, Daniel Amador-Noguez ${ }^{1}$, Jing Fan ${ }^{1,3}$, Joshua Rabinowitz ${ }^{1,3}$ \\ From Metabolism, Diet and Disease 2014: Cancer and metabolism \\ Washington DC, USA. 28-30 May 2014
}

\section{Background}

Current technological limitations hinder the measurement of certain core metabolites, including glyceraldehyde-3phosphate and erythrose-4-phsophate. For measurable metabolites, absolute concentration data sets are not always thermodynamically consistent. The use of a previously underappreciated thermodynamic relationship, however, provides a way to remedy these shortcomings. We develop a novel approach to integrate metabolite concentrations, reaction fluxes, and reaction free energies $\left(\Delta_{\mathrm{r}} \mathrm{G}\right)$ and apply it across four organisms: E. coli, C. acetobutylicum, Baker's yeast, and mouse renal epithelial cells.

\section{Materials and methods}

Microbes were grown in 1,2-13C, 3-13C, U-13C, and 50\% U-13C glucose minimal media. Mouse renal epithelial cells were cultured in 1,2-13C glucose, U-13C glucose, and U-13C glutamine Dulbecco's Modified Eagle Media, supplemented with $10 \%$ dialyzed fetal bovine serum. We measured intracellular isotope distributions via LC/MS and calculated absolute metabolite concentrations using an isotope-ratio-based approach [1]. Nutrient uptake and metabolite excretion rates were determined by $1 \mathrm{H}-\mathrm{NMR}$. Standard reaction free energies $\left(\Delta_{\mathrm{r}} G^{\circ}\right)$ were computed using component contribution [2] at physiological $\mathrm{pH}$ and ionic strength.

\section{Results}

Our approach was applied to yield in vivo $\Delta_{\mathrm{r}} \mathrm{G}$ values and metabolite concentrations in E. coli, C. acetobutylicum,
Baker's yeast, and mouse renal epithelial cells. For each organism, free energies for many reactions in central carbon, biosynthesis, and folate metabolism were determined from ratios of forward to reverse fluxes. We combined these values with concentration measurements for $\sim 100$ metabolites and $\Delta_{\mathrm{r}} \mathrm{G}^{\circ}$ values to determine global core metabolite concentrations more completely and precisely. In general, amino acids comprise a large fraction of the total metabolite pool. Energy charge was higher in mammalian and $E$. coli cells whose main route of ATP generation is through oxidative phosphorylation. Certain reversible reactions of glycolysis (fructose-bisphosphate aldolase and triose-phosphate isomerase) were also more strongly forward driven in the oxidative cell types, especially in the mammalian cells, perhaps reflecting minimal need to maintain equilibrium at these steps when ample free energy is available via other routes.

\section{Conclusions}

Integrative analysis of metabolite concentrations with reaction fluxes and free energies should enable substantially more comprehensive and precise characterization of cellular metabolic activity.

\section{Authors' details \\ ${ }^{1}$ Lewis-Sigler Institute for Integrative Genomics, Princeton University, Princeton, NJ, USA. ${ }^{2}$ Department of Chemical and Biological Engineering, Princeton University, Princeton, NJ, USA. ${ }^{3}$ Department of Chemistry, Princeton University, Princeton, NJ, USA.}




\section{References}

1. Bennett BD, Yuan J, Kimball EH, Rabinowitz JD: Absolute quantitation of intracellular metabolite concentrations by an isotope ratio-based approach. Nat Protoc 2008, 3:1299-311.

2. Noor E, Haraldsdóttir HS, Milo R, Fleming RMT: Consistent estimation of Gibbs energy using component contributions. PLoS Comput Biol 2013, 9 . e1003098.

doi:10.1186/2049-3002-2-S1-P54

Cite this article as: Park et al:: Comprehensive quantitation of metabolite concentrations, gross reaction fluxes, and reaction free energies across cells from four organisms. Cancer \& Metabolism 2014 2(Suppl 1):P54.

\section{Submit your next manuscript to BioMed Central} and take full advantage of:

- Convenient online submission

- Thorough peer review

- No space constraints or color figure charges

- Immediate publication on acceptance

- Inclusion in PubMed, CAS, Scopus and Google Scholar

- Research which is freely available for redistribution

Submit your manuscript at www.biomedcentral.com/submit
Ciomed Central 